\title{
REVIEW
}

Open Access

\section{Neoadjuvant endocrine therapy in locally advanced estrogen or progesterone receptor-positive breast cancer: determining the optimal endocrine agent and treatment duration in postmenopausal women-a literature review and proposed guidelines}

Lauren I. Madigan ${ }^{1,2}$, Phuong Dinh ${ }^{1,3}$ and J. Dinny Graham ${ }^{1,3,4^{*}}$ (D)

\begin{abstract}
Introduction: For patients with locally advanced estrogen receptor or progesterone receptor-positive breast cancer, neoadjuvant endocrine therapy (NET) facilitates down-staging of the tumor and increased rates of breastconserving surgery. However, NET remains under-utilized, and there are very limited clinical guidelines governing which therapeutic agent to use, or the optimal duration of treatment in postmenopausal women. This literature review aims to discuss the evidence surrounding (1) biomarkers for patient selection for NET, (2) the optimal neoadjuvant endocrine agent for postmenopausal women with locally advanced breast cancer, and (3) the optimal duration of NET. In addition, we make initial recommendations towards developing a clinical guideline for the prescribing of NET.
\end{abstract}

Method: A wide-ranging search of online electronic databases was conducted using a truncated PIC search strategy to identify articles that were relevant to these aims and revealed a number of key findings.

(Continued on next page)

\footnotetext{
* Correspondence: dinny.graham@sydney.edu.au

${ }^{1}$ Sydney Medical School - Westmead, The University of Sydney, Sydney,

Australia

${ }^{3}$ Westmead Breast Cancer Institute, Westmead Hospital, Westmead, Australia

Full list of author information is available at the end of the article
}

(c) The Author(s). 2020 Open Access This article is licensed under a Creative Commons Attribution 4.0 International License, which permits use, sharing, adaptation, distribution and reproduction in any medium or format, as long as you give appropriate credit to the original author(s) and the source, provide a link to the Creative Commons licence, and indicate if changes were made. The images or other third party material in this article are included in the article's Creative Commons licence, unless indicated otherwise in a credit line to the material. If material is not included in the article's Creative Commons licence and your intended use is not permitted by statutory regulation or exceeds the permitted use, you will need to obtain permission directly from the copyright holder. To view a copy of this licence, visit http://creativecommons.org/licenses/by/4.0/ The Creative Commons Public Domain Dedication waiver (http://creativecommons.org/publicdomain/zero/1.0/) applies to the data made available in this article, unless otherwise stated in a credit line to the data. 
(Continued from previous page)

Results: Randomized trials have consistently demonstrated that aromatase inhibitors are more effective than tamoxifen, in terms of objective response rate and rate of BCS, and should be used as first-line NET. The three available aromatase inhibitors have so far been demonstrated to be biologically equivalent, with the choice of aromatase inhibitor not having been shown to affect clinical outcomes. There is increasing evidence for extending the duration of NET beyond 3 to 4 months, to at least 6 months or until maximal clinical response is achieved. While on-treatment levels of the proliferation marker Ki67 are predictive of long-term outcome, the choice of adjuvant therapy in patients who have received NET and then surgery is best guided by the preoperative endocrine prognostic index, or PEPI, which incorporates Ki67 with other clinical parameters.

Conclusion: This study reveals that in appropriately selected patients, NET can provide equivalent clinical benefit to neoadjuvant chemotherapy in the same cohort, if suitable treatments and durations are chosen. Our findings highlight the need for better defined biomarkers both for guiding patient selection and for measuring outcomes. Development of standard guidelines for the prescribing of NET has the potential to improve both clinical outcomes and quality of life in this patient cohort.

Keywords: Neoadjuvant endocrine therapy, Selective estrogen receptor modulators, Aromatase inhibitors

\section{Introduction}

Breast cancer is the most common cancer affecting women, with a one in seven lifetime risk [1]. Each year, approximately two million women are diagnosed with breast cancer worldwide [2, 3]. Estrogen receptor (ER)positive and/or progesterone receptor (PgR)-positive breast cancer accounts for approximately $70 \%$ of all breast cancers, and $85 \%$ of those in women over 70 years of age [4-6]. At the time of diagnosis, 7 to $20 \%$ of women will present with locally advanced breast cancer (LABC) [7-9]. LABC is defined as tumors that are $>50$ $\mathrm{mm}$ in size or involve the skin of the breast/chest wall, multiple axillary lymph nodes, or the supra/infraclavicular lymph nodes [10]. The percentage of patients diagnosed with LABC in a particular population is largely dependent of the rate and effectiveness of mammography screening $[11,12]$. Data from the USA shows that LABC is more likely to affect racial or ethnic minority groups, in particular African Americans, where 12\% are diagnosed with LABC compared to $8 \%$ in white American populations $[11,13]$. This likely results from health inequities such as poverty, rurality, and reduced rates of health insurance which create barriers in accessing health care programs such as preventative screening [11, 14]. Women under the age of 40 may also be more likely to present with LABC as mammography is not routinely recommended in this group [11]. Similarly, on a global scale, LABC is more likely to be diagnosed in underdeveloped countries, where rates of LABC can reach up to $60 \%[11,12,15]$.

Breast cancer, for the majority of patients, is treated with upfront surgery followed by other adjuvant (postoperative) modalities including radiotherapy, chemotherapy, or endocrine therapy $[16,17]$. However, for women with LABC, breast-conserving surgery (BCS) is not an option at the time of diagnosis, and there is potential benefit in a neoadjuvant, or pre-operative approach, to chemotherapy or endocrine treatment. The goal of neoadjuvant therapy is to reduce the pre-surgical tumor burden and increase the rate of BCS in mastectomy candidates, or allow operability of a previously inoperable tumor $[18,19]$. The advantages of BCS include a reduction in surgical morbidity and mortality and improvement in cosmetic outcomes [17]. Neoadjuvant approaches also provide prognostic and predictive information $[18,20,21]$.

Despite $\mathrm{ER}^{+}$breast cancer being the most common subtype of breast cancer [4], clinical guidelines for the neoadjuvant treatment of patients with $\mathrm{ER}^{+} \mathrm{LABC}$ are inconsistent or lacking in most settings. There are data to suggest that neoadjuvant chemotherapy (NCT) produces the same overall and disease-free survival rate as adjuvant chemotherapy for $\mathrm{ER}^{-}$tumors, with increased rates of BCS [22-25]. However, it is also well recognized that $\mathrm{ER}^{+}$tumors often respond poorly to $\mathrm{NCT}$ and therefore require robust alternatives [22-25]. Unfortunately, the adoption of neoadjuvant endocrine therapy (NET) for $\mathrm{ER}^{+}$tumors has been much slower. Three categories of NET are available: selective ER modulators (primarily tamoxifen), selective ER degraders (fulvestrant), and aromatase inhibitors (including letrozole, anastrozole, and exemestane) which block estrogen synthesis [26]. Historically, NET was reserved for patients who were considered too frail or unsuitable for surgery or chemotherapy; however, recent evidence is leading to the expansion of this treatment group [27, 28]. Three to 4 months of NET causes tumor shrinkage in two-thirds of patients and can convert up to $50 \%$ of mastectomy candidates into BCS candidates [21, 29]. Despite this, NET in breast cancer has been inadequately investigated and utilized compared to NCT, and the optimal duration of treatment remains unknown [30]. 
This review examines the application of NET in postmenopausal women with locally advanced ER and/or PgR-positive breast cancer. There are currently limited clinical guidelines outlining which neoadjuvant endocrine agent to use, or the optimal duration of use, in postmenopausal women with $\mathrm{ER}$ and/or $\mathrm{PgR}^{+}$breast cancer. In this study, we aimed to investigate biomarkers for determining patient selection and monitoring treatment response, compare outcomes between tamoxifen and aromatase inhibitors, determine the optimal duration of NET, and make initial recommendations as a basis for clinical guideline development.

\section{Methods}

\section{Search strategy}

Multiple online electronic databases (PubMed, MEDL INE, and PREMEDLINE) were searched several times during the study period, the most recent being December 2019, using appropriate keywords and MeSH subheadings (Additional file 1, Table S1). The topic areas identified for the search were breast neoplasms, $E R^{+} /$ $P g R^{+}$status, postmenopausal women, and neoadjuvant endocrine therapy. As pathological complete response is rare in $\mathrm{ER}^{+}$breast cancer, there is often inconsistency in the outcome measures used in studies of NET. Consequently, an outcome measure was not included in the PICO search as this would have excluded a large number of relevant studies. This truncated PIC approach has been previously validated as preferable to the PICO model when conducting a systematic review search, to prevent excluding studies which do not use the specified outcome measure and consequently reducing the sensitivity of the search $[31,32]$. The initial search produced 170 papers, of which the abstracts were reviewed to ensure the inclusion and exclusion criteria were met. The reference lists of relevant studies and reviews were used to identify further relevant literature.

\section{Inclusion criteria}

Inclusion criteria include postmenopausal, female, and $\mathrm{ER}^{+}$or $\mathrm{PgR} \mathrm{R}^{+}$breast cancer.

\section{Exclusion criteria}

Exclusion criteria include metastatic, inflammatory, triple negative, $\mathrm{HER}_{2}{ }^{+}$or male breast cancer, prior breast cancer treatment, recent hormonal therapy, and articles published in a language other than English.

\section{Limits}

There was no cut-off date for literature inclusion, and no restriction on the type of study included in the review as this is a relatively small and under-investigated field and we did not want to limit the scope of the review.
A glossary of terms used and their definitions is given in Additional file 1, Table S2.

No conflict of interest was identified.

\section{Results \\ Biomarkers}

In order for neoadjuvant trials to be of value, reliable biomarkers for patient selection and treatment response must be available. It is known that NCT is less likely to result in a pathological complete response (pCR) in $\mathrm{ER}^{+}$ tumors compared to $\mathrm{ER}^{-}$tumors, making NET a valuable alternative in these patients [33, 34]. Typically, patients with $\mathrm{LABC}$ who are treated with NET will receive post-surgical adjuvant treatment with endocrine therapy with or without chemotherapy. The adjuvant treatment recommendation is guided by the response of the tumor to NET and the estimated risk of recurrence based on the evaluation of the surgical specimen. The German Breast Group NCT trial showed a pCR rate of $22.8 \%$ in $\mathrm{ER}^{-}$tumors, compared to only $6.2 \%$ in $\mathrm{ER}^{+}$tumors $[16$, 35]. Rates of $\mathrm{pCR}$ for $\mathrm{ER}^{+}$tumors treated with NET are typically as low as $3 \%$; however, this figure may be increased with a longer treatment duration [29]. Consequently, pCR is rarely used as an outcome measure in studies of $\mathrm{ER}^{+}$tumors. A number of different biomarkers exist which will be discussed in the following sections. Biomarkers currently in use for patient selection include high ER or PgR expression and gene expression profiling (low pre-treatment recurrence score (RS) or a high ER pathway activity score). Biomarkers with prognostic value include on-treatment and post-treatment Ki67, the preoperative endocrine prognostic index (PEPI) and PPEPI, and post-treatment RS.

\section{$E R / P g R$}

Patients who have $\mathrm{ER}^{+}$and/or PgR ${ }^{+}$tumors show markedly improved surgical outcomes with NET compared to $\mathrm{ER}^{-} \mathrm{PgR} \mathrm{R}^{-}$tumors [36]. ER expression is commonly reported as an Allred Score, which combines a score for the proportion of positive cells, and an intensity score (Additional file 1. Table S3) [37]. Tumors with an Allred Score of $0-2$ are $E R^{-}$, and those with a score of 3-8 are $\mathrm{ER}^{+}$[37]. A study investigating 12 months of neoadjuvant letrozole demonstrated that the likelihood of a positive response to NET increased by $7 \%$ for each $1 \%$ increase in ER expression [29]. However, analysis of the large P024 trial (4 months of neoadjuvant letrozole vs. tamoxifen) showed that patients with less than $10 \% \mathrm{ER}^{+}$ cells may still derive benefit from neoadjuvant letrozole, but not tamoxifen, and caution should be observed with a $10 \%$ cut-off $[16,36]$. Currently, many studies use an ER expression threshold of $50 \%$ to try to maximize response, which may be excluding a large proportion of eligible patients [38]. The results of the 2019 St. Gallen 
conference recommend that any tumor with $\geq 1 \%$ ER expression be treated with adjuvant endocrine therapy [39]. Since not all $\mathrm{ER}^{+}$tumors respond to aromatase inhibitors, there is a current need for additional biomarkers to predict patient response [40].

\section{Ki67}

The Ki67 antigen is an accessible and convenient proliferation marker [41, 42]. The P024 trial demonstrated that pre-treatment tumor Ki67 levels were not correlated with relapse-free survival (RFS); however, a lower posttreatment Ki67 level was significantly associated with increased RFS [41]. On or post-treatment Ki67 levels predict relapse risk with greater accuracy than baseline Ki67 levels, whether this is measured at several weeks postNET initiation (IMPACT trial) or after 3 to 4 months [41]. Additionally, a study of 12 months of neoadjuvant letrozole demonstrated that post-treatment Ki67, along with residual tumor burden, were the only predictors of progression-free survival (PFS) [29]. Ideally, a measurement of the absolute Ki67 level on the surgical biopsy sample would guide treatment decisions; however, the statistical significance of this approach is weaker compared to looking at the percentage decrease in Ki67 [20]. In contrast, a 2018 study assessing biomarkers for predicting response to NET found that Ki67 did not predict complete response or pCR, agreeing with the results of the IMPACT trial [43].

\section{Gene expression profiling}

Gene expression profiling (GEP) uses multi-gene prognostic signatures that measure expression levels of a defined set of mRNA transcripts in a treatment-naïve breast tumor to provide additional information to existing pathological variables, which enable the accurate prediction of probability of disease recurrence and identify clinically different disease subtypes [44]. GEP is currently used to stratify breast cancer into its intrinsic subtypes: HER-2 enriched, luminal A and B, basal-like and normal-like $[45,46]$. Luminal A and B tumors correspond to hormone receptor-positive tumors and are distinguished based on their proliferation status [45]. Accordingly, commercial multi-gene assays are now endorsed by the American Society of Clinical Oncology, St. Gallen/European Society for Medical Oncology and National Comprehensive Cancer Network guidelines, for guiding treatment decisions in the adjuvant setting for $\mathrm{ER}^{+}$breast cancers $[3,39]$. More recently, their utility has also been demonstrated for clinical management after neoadjuvant treatment $[47,48]$.

The recurrence score (RS) is an example of GEP developed primarily to predict distance recurrence of breast cancer in the adjuvant setting [49]. The Oncotype DX 21-gene expression profile assay gives rise to the validated RS between 0 and 100 for women with nodenegative $\mathrm{ER}^{+}$breast cancer, representing the risk of recurrence at 10 years $[49,50]$. The 10 -year risk of distant recurrence for a $\mathrm{RS}<18$ was $6.8 \%$ compared to $30.5 \%$ for those with a $R S \geq 31[42,51]$. A high RS usually involves ER and PR negativity, HER2 positivity, and a high nuclear grade and mitotic count [50]. While a high RS is associated with pCR following NCT, the data for NET did not reach statistical significance [50]. However, it was speculated that patients with a low RS will achieve a greater response to NET [50]. A more recent multicenter phase II trial with neoadjuvant exemestane demonstrated that combining the pre-treatment and posttreatment RS had a greater prognostic value in patients receiving NET in terms of disease-free survival $(p=$ 0.0096) while the pre-treatment RS alone did not reach significance [48]. Additionally, the TransNEOS study aimed to evaluate whether the RS could act as a biomarker and predict clinical response to neoadjuvant letrozole and concluded that the post-treatment RS was able to predict clinical response $(p=0.009)$ [52]. Among patients with a RS $<18,54 \%$ achieved a complete or partial response and $79 \%$ were candidates for BCS, compared to a higher rate of progressive disease in those with a RS $\geq 31$ [52]. A study by Bear et al. used the RS to allocate treatment in patients with $\mathrm{ER}^{+}$tumors who were not candidates for BCS at baseline; with patients with a RS $<11$ receiving NET, patients with a RS $\geq 26$ receiving NCT and those with a RS from 11 to 25 being randomized to NET or NCT [49]. Rates of clinical response (complete and partial responses) were significantly associated with the RS group; however, rates of successful BCS did not vary significantly between the three groups [49].

Given that most existing multi-gene tests primarily predict risk of disease recurrence and benefit from chemotherapy, they do not directly indicate likely endocrine responsiveness and may not be ideal for patient selection. An assay that estimates ER activity could more accurately predict benefit from NET [47]. Inda and colleagues evaluated an ER pathway activity score, or ERPA S, comprising measurement of the expression 27 "high evidence ER target genes" in pre- and post-treatment tumors and reported that around one-third of $\mathrm{ER}^{+}$tumors had an inactive ER pathway activity score at baseline [47]. Tumors that responded to NET had a higher pretreatment ERPAS and a greater magnitude of decrease after 2 weeks of treatment [47]. This score may be used to identify the group of patients with $\mathrm{ER}^{+}$tumors who will be non-responders to endocrine therapy [47].

\section{PEPI}

The randomized P024 trial was used to generate a model to predict relapse risk in patients who receive NET, the preoperative endocrine prognostic index (PEPI) [41]. The 
PEPI analyzes the post-surgical specimen and combines tumor size (T1/2 vs. T3/4), nodal status (positive or negative), Ki67 level, and ER Allred Score (0-2 vs. 3-8), which were all associated with RFS, to give a score of $0,1-3$, or $\geq$ 4. (Additional file 1. Table S4) [41]. The scores of 0, 1-3, and $\geq 4$ give relapse risks of 10,23 , and $48 \%$, respectively [41]. Clinically, the PEPI is able to identify patients who do not require adjuvant chemotherapy due to low relapse risk [41]. In contrast, patients with a high PEPI should receive all appropriate adjuvant therapies [41]. The risk of relapse is extremely low in patients who receive a PEPI score of 0 , as validated by both the P024 and IMPACT trials $[26,53]$. In the CARMINA 02 trial, there was a significant increase in relapse risk for patients with a PEPI score $\geq 4$, the only variable which was predictive of RFS [28]. NET may be especially important for patients with luminal A tumors, as approximately $25 \%$ of these patients have a PEPI score of $0[54,55]$. PgR, which is a known discriminator of luminal A and B tumors, might strengthen prognostic power when combined with the PEPI score [56]. In a study of 107 post-menopausal patients receiving neoadjuvant exemestane for at least 4 months, pretreatment PgR positivity $>50 \%$ was significantly associated with recurrence-free and cancer-specific survival [57]. When PgR was combined as a binary marker with the PEPI score, the PEPI-P was a significantly stronger predictor of outcome than PEPI alone [57]. It will be important to validate the PEPI-P score in a larger cohort, and overall PEPI validation efforts should continue.

\section{Emerging biomarkers}

The candidate oncogene ZNF217 has been recently proposed as a biomarker to assess the clinical response to NET in $\mathrm{ER}^{+}$breast cancer, with high levels of ZNF217 associated with reduced responses to NET in a prospective study [58]. Interestingly, the low and high ZMF217 groups were similar at baseline in terms of their Ki67 levels so ZMF217 is unlikely to be simply a marker of cellular proliferation [58]. A recent study found an association between partial response to NET in $\mathrm{ER}^{+}$tumors and the genes KRAS, CUL2, FAM13A, ADCK2, and LILRA2 [43]. Higher levels of KRAS, MMS19, and IVD were correlated with a PEPI score $\leq 3$; however, these genes had limited correlation with Ki67 reduction to $\leq 10 \%$ [43].

Recommendation: Patients with a PEPI score of 0 at surgery may be spared adjuvant systemic treatment. Patients with PEPI score $>0$ should receive adjuvant therapies as per local oncology practice and the patients' clinical features. The clinical role of Ki67 is currently unresolved.

\section{Choice of neoadjuvant endocrine agent}

There have been three large randomized controlled trials comparing tamoxifen to aromatase inhibitors; each demonstrating either superiority or non-inferiority of aromatase inhibitors in the neoadjuvant setting [16, 19, $59,60]$. Tamoxifen is a long-standing treatment for breast cancer; however, it may lead to serious adverse effects including thromboembolism and endometrial cancer [59]. Additionally, tamoxifen resistance is not uncommon, yet approximately one-third of patients with resistance to tamoxifen will still benefit from aromatase inhibition [61]. Aromatase inhibitors block the peripheral conversion of androgen to estrogen, reducing circulating estrogen levels by up to $90 \%$ [62].

The P024 trial is the largest trial comparing neoadjuvant tamoxifen and letrozole in postmenopausal women with $\mathrm{ER}^{+}$breast cancer who were ineligible for $\mathrm{BCS}[16,59]$. Letrozole led to a significantly greater objective response rate (ORR) and rate of BCS (Table 1) [59]. Response rates in the letrozole group were higher than for tamoxifen in all Allred Scores from 3 to 8, demonstrating letrozole's superiority independently of ER expression level [36]. The most common adverse events in this trial were hot flushes and nausea, which occurred equally with tamoxifen and letrozole (57\% of patients in each group) [59].

Two large trials compared neoadjuvant tamoxifen and anastrozole (Table 1). In terms of ORR, both the PROACT and IMPACT trials demonstrated noninferiority of anastrozole to tamoxifen $[19,60]$. In terms of $\mathrm{BCS}$, the PROACT trial showed a significantly higher rate in patients taking anastrozole; however, this rate did not reach significance in the IMPACT trial (Table 1) $[19,60]$. Hot flushes were the most common adverse event on both medications; however, anastrozole had a lower rate of vaginal discharge and thromboembolic events in the IMPA CT trial [19]. Additional studies which demonstrate the superiority of aromatase inhibitors in comparison to tamoxifen are summarized in Table $1[63,64]$.

There have also been a number of trials comparing different aromatase inhibitors, or aromatase inhibitors with fulvestrant, a selective estrogen receptor degrader (Table 2) [26]. Overall, these studies have not been able to demonstrate superiority of one aromatase inhibitor over another. In terms of ORR, the largest trial (Z1031 trial) did not demonstrate a significant difference between exemestane (62.9\%), letrozole (74.8\%), and anastrozole (69.1\%) (Table 2) $[53,54]$. Other studies comparing aromatase inhibitors also did not demonstrate superiority of any one agent (Table 2 ) $[28,65,66]$. In terms of the BCS rate, there was no significant difference found between the types of aromatase inhibitors or fulvestrant (Table 2) [28, 53, 54, 65, 66].

Following the determination that all three aromatase inhibitors showed biological equivalence, the Z1031 trial created an extension study known as Z1031B [53, 54]. In the Z1031B trial, patients who had a Ki67 >10\% after 2 to 4 weeks of NET were switched to chemotherapy in an attempt to increase the rate of $\mathrm{pCR}$ [53]. Based on the IMPACT trial and Preoperative Letrozole study, patients with a Ki67 > 10\% 
Table 1 Tamoxifen vs. aromatase inhibitors in the neoadjuvant setting

\begin{tabular}{|c|c|c|c|c|c|}
\hline Study & $\begin{array}{l}\text { Duration } \\
\text { (months) }\end{array}$ & Dose (mg/day) & $\begin{array}{l}\text { No. of } \\
\text { patients }\end{array}$ & Study outcomes & Assessment \\
\hline $\begin{array}{l}\text { P024 Trial Eiermann et al. } \\
2001 \text { [59] }\end{array}$ & 4 & $\begin{array}{l}\text { Letrozole } 2.5 \text { or } \\
\text { tamoxifen } 20\end{array}$ & 324 & $\begin{array}{l}\text { 1. pCR: } 1.3 \% \text { letrozole; } \\
\text { 1.8\% tamoxifen } \\
\text { 2. ORR (clinical palpation): } \\
\text { 55\% letrozole; } 36 \% \text { tamoxifen } \\
\text { ( } p<0.0001) \text {. ER } R^{+} \text {subgroup: } 60 \% \\
\text { letrozole; } 41 \% \text { tamoxifen. } \\
\text { 3. BCS: } 45 \% \text { letrozole; } 35 \% \\
\text { tamoxifen ( } p=0.022)\end{array}$ & $\begin{array}{l}\text { Monthly clinical palpation and } \\
\text { ultrasound. Mammography at } \\
\text { baseline and prior to surgery. }\end{array}$ \\
\hline $\begin{array}{l}\text { PROACT Cataliotti et al. } \\
2006 \text { [60] }\end{array}$ & 3 & $\begin{array}{l}\text { Anastrozole } 1 \text { or } \\
\text { tamoxifen } 20 \pm \text { NCT }\end{array}$ & 451 & $\begin{array}{l}\text { 1. pCR: NR. } \\
\text { 2. ORR (clinical palpation): } 49.7 \% \\
\text { anastrozole; } 39.7 \% \text { tamoxifen } \\
(p>0.5, \text { NET only) } \\
\text { 3. BCS: } 43 \% \text { anastrozole; } 30.8 \% \\
\text { tamoxifen ( } p=0.04 \text {, NET only) }\end{array}$ & $\begin{array}{l}\text { Ultrasound and caliper } \\
\text { measurements at baseline } \\
\text { and } 3 \text { months. }\end{array}$ \\
\hline IMPACT Smith et al. 2005 [19] & 3 & $\begin{array}{l}\text { Anastrozole } 1 \text { or } \\
\text { tamoxifen } 20 \text { or } \\
\text { combination }\end{array}$ & 330 & $\begin{array}{l}\text { 1. pCR: NR. } \\
\text { 2. ORR (clinical palpation): } 37 \% \\
\text { anastrozole; } 36 \% \text { tamoxifen; } 39 \% \\
\text { combination ( } p=0.87) \\
\text { 3. BCS: } 44 \% \text { anastrozole; } 31 \% \\
\text { tamoxifen; } 24 \% \text { combination } \\
\text { ( } p=0.23, \text { mastectomy at baseline) }\end{array}$ & $\begin{array}{l}\text { Clinical caliper measurements } \\
\text { and ultrasound at baseline, } 2 \text {, } \\
6 \text { and } 12 \text { weeks. }\end{array}$ \\
\hline Akashi-Tanaka et al. 2007 [63] & $\begin{array}{l}5 \text { (Anastrozole) or } \\
4 \text { (Tamoxifen) }\end{array}$ & $\begin{array}{l}\text { Anastrozole } 1 \text { or } \\
\text { tamoxifen } 20\end{array}$ & 45 & $\begin{array}{l}\text { 1. pCR: not reported. } \\
\text { 2. ORR (clinical palpation): } 76.5 \% \\
\text { anastrozole; } 46.4 \% \text { tamoxifen } \\
\text { 3. BCS: not reported. }\end{array}$ & Monthly clinical assessment. \\
\hline Semiglazov et al. 2005 [64] & 3 & $\begin{array}{l}\text { Exemestane } 25 \text { or } \\
\text { tamoxifen } 20\end{array}$ & 151 & $\begin{array}{l}\text { 1. pCR: } 2.6 \% \text { exemestane; } \\
\text { 2.7\% tamoxifen } \\
\text { 2. ORR (clinical palpation): } 76.3 \% \\
\text { exemestane; } 40 \% \text { tamoxifen } \\
(p=0.05) \\
\text { 3. BCS: } 36.8 \% \text { exemestane; } 20 \% \\
\text { tamoxifen ( } p=0.05 \text { ) }\end{array}$ & Not reported. \\
\hline
\end{tabular}

$B C S$ breast-conserving surgery, $p C R$ pathological complete response, $O R R$ objective response rate, $C R$ complete response, $P R$ partial response, $N R$ not reported. See Additional file 1, Table S2 for definitions

were found to have $\mathrm{a}<2 \%$ chance of obtaining PEPI $=0$ and, hence, avoiding adjuvant chemotherapy $[19,53,67]$. Of the patients who switched to NCT, only $5.7 \%$ (2 patients) went on to achieve a pCR [53]. In patients who had a 2-week Ki67 $<10 \%$ and received 16 weeks of NET, the pCR rate was $1.6 \%$ and the PEPI $=0$ rate was $34.4 \%$ [53].

The ALTERNATE trial is a phase III trial currently in recruitment which aims to compare anastrozole, fulvestrant, or their combination and identify women at a low risk of recurrence based on the PEPI [26]. After 4 weeks of treatment, women with a Ki67 >10\% will be switched to NCT, and only women with a PEPI $=0$ postsurgery will receive adjuvant endocrine therapy [26].

Recommendation: If suitable for NET, post-menopausal patients with $\mathrm{ER}^{+}$ and/or $\mathrm{PgR}^{+} \mathrm{LABC}$ should receive aromatase inhibitors as first-line neoadjuvant therapy. The choice of aromatase inhibitor should be guided by local clinical practice and has not been shown to affect outcomes.

\section{Duration of neoadjuvant endocrine therapy}

Despite the advantages of aromatase inhibitors being clearly highlighted in the P024 and Z1031A trials, there is continual limited use by physicians [68]. A study from the USA revealed only $3.1 \%$ of women with ER and/or $\mathrm{PgR}^{+}$breast cancer received NET compared to $24.7 \%$ who received NCT [69]. However, this figure has slowly increased from $2.3 \%$ (2004) to $3.5 \%$ (2014), with women treated in academic rather than community centers more likely to receive NET [69]. In addition, this study found women were more likely to receive NET if they were $>60$ years old and had tumors with a lower grade or stage III disease [69]. Potential barriers to widespread adoption of NET include the heterogenous nature of patient responses, and the long duration required to achieve a clinical response [53]. The reluctance to introduce NET into clinical practice may also represent the poor response rates seen when treatment is carried out for a duration of only 3 to 4 months [30]. In comparison to NCT, NET has more gradual effect on the tumor and an extended treatment period is usually required in order to appreciate the maximum clinical response [70].

The optimal duration of NET that should be administered to postmenopausal patients with $\mathrm{ER}^{+}$ 
Table 2 Comparison of aromatase inhibitors and fulvestrant

\begin{tabular}{|c|c|c|c|c|c|}
\hline Study & $\begin{array}{l}\text { Duration } \\
\text { (months) }\end{array}$ & Dose (mg/day) & $\begin{array}{l}\text { No. of } \\
\text { patients }\end{array}$ & Study outcomes & Assessment \\
\hline $\begin{array}{l}\text { Z1031 trial. Ellis et al. } 2011 \\
\text { and } 2017[53,54]\end{array}$ & 4 & $\begin{array}{l}\text { Exemestane } 25 \text { or } \\
\text { letrozole } 2.5 \text { or } \\
\text { anastrozole } 1\end{array}$ & 377 & $\begin{array}{l}\text { 1. pCR: } 1.6 \% \text { (Al } 16 \text { weeks); } \\
\text { 5.7\% (switched to } \\
\text { chemotherapy at } 2 \text { weeks) } \\
\text { 2. ORR (clinical palpation): } \\
\text { 62.9\% exemestane; } 74.8 \% \\
\text { letrozole; } 69.1 \% \text { anastrozole. } \\
\text { 3. BCS: } 51 \% \text { (patients } \\
\text { mastectomy at baseline); } \\
83 \% \text { (patients marginal } \\
\text { for BCS) }\end{array}$ & $\begin{array}{l}\text { Monthly physical } \\
\text { examination, toxicity } \\
\text { assessment, and tumor } \\
\text { assessment. }\end{array}$ \\
\hline CARMINA 02 Lerebours et al. 2016 [28] & 4 or 6 & $\begin{array}{l}\text { Anastrozole } 1 \text { or } \\
\text { fulvestrant } \\
500 \mathrm{mg} / \mathrm{month}\end{array}$ & 116 & $\begin{array}{l}\text { 1. pCR: NR. } \\
\text { 2. ORR (clinical palpation): } \\
\text { 52.6\% anastrozole; } 36.8 \% \\
\text { fulvestrant. } \\
\text { 3. BCS: } 57.6 \% \text { anastrozole; } \\
\text { 50\% fulvestrant ( } p=0.5 \text { ) }\end{array}$ & $\begin{array}{l}\text { Clinical assessment, } \\
\text { ultrasound, and MRI at } \\
\text { baseline, } 1 \text { month, and } \\
4 \text { months. }\end{array}$ \\
\hline Grassadonia et al. 2014 [65] & Mean 5.7 & $\begin{array}{l}\text { Anastrozole } 1 \text { or } \\
\text { exemestane } 25 \text { or } \\
\text { letrozole } 2.5\end{array}$ & 144 & $\begin{array}{l}\text { 1. pCR: } 1.4 \% \\
\text { 2. ORR (clinical palpation): } \\
86.6 \% \text { ( } 9.6 \% \text { CR and } 77 \% \text { PR) } \\
\text { 3. BCS: } 84 \% \text { (ineligible for } \\
\text { BCS at baseline) }\end{array}$ & $\begin{array}{l}\text { Caliper measurement } \\
\text { at baseline, monthly, } \\
\text { and before surgery. }\end{array}$ \\
\hline FIRST Robertson et al. 2009 [66] & Until progression & $\begin{array}{l}\text { Anastrozole } 1 \text { or } \\
\text { fulvestrant } \\
500 \mathrm{mg} / \mathrm{month}\end{array}$ & 205 & $\begin{array}{l}\text { 1. pCR: NR. } \\
\text { 2. ORR (clinical palpation): } \\
\text { 35.5\% anastrozole; } 36 \% \\
\text { fulvestrant ( } p=0.947) \\
\text { 3. BCS: NR. }\end{array}$ & $\begin{array}{l}\text { Clinical and radiological } \\
\text { tumor assessment every } \\
12 \pm 2 \text { weeks until } \\
\text { progression. }\end{array}$ \\
\hline
\end{tabular}

$B C S$ breast-conserving surgery, $p C R$ pathological complete response, $O R R$ objective response rate, $C R$ complete response, $P R$ partial response, $N R$ not reported. See Additional file 1, Table S2 for definitions

breast cancer has not yet been determined or incorporated into clinical guidelines [18, 27, 71-73]. The majority of NET randomized trials use a treatment duration of 3 to 4 months, which is largely arbitrary and related to historical studies of tamoxifen and chemotherapy [30, 73]. At the 2013 St. Gallen breast cancer conference, $62.2 \%$ of panelists supported NET being given until maximal response [74, 75]. An additional $26.7 \%$ of panelists supported a duration of 4 to 8 months, while only $11.1 \%$ supported the current duration of 3 to 4 months [75]. One of the major concerns of extending NET until maximal response is the risk of disease progression. A study by Carpenter et al. aiming to identify the optimal duration of letrozole therapy had a low progression rate of $6.5 \%$ [30]. Similarly, a study of neoadjuvant exemestane showed a $7.7 \%$ progression rate at 4 months, increasing to only $8 \%$ at 6 months of treatment [76]. Despite the evidence, 4 years on at the 2017 St. Gallen conference, uptake of NET remained suboptimal with the panel stating that "Neoadjuvant ET in postmenopausal women with $\mathrm{ER}^{+}$ stage II/III tumors is currently underused, although it shows low toxicity" [68]. Six years later at the 2019 St. Gallen International Breast Cancer Conference, there is extremely limited attention given to the neoadjuvant treatment of $\mathrm{ER}^{+}$tumors and no clinical guidelines or recommendations are made [39].
Recently, there have been several small studies aiming to investigate the optimal duration of NET, only two of which were randomized trials. In the four studies where the duration of NET was extended to 12 months, the ORR's ranged from 76.8 to $95 \%$, and the rate of BCS was 45 to $87.5 \%$ (Table 3) [27, 29, 30, 73]. In contrast, the large PROACT and IMPACT trials, discussed previously, used a duration of 3 months and reported an ORR of only 49.7 and 37\%, respectively, with BCS rates of 43 and $44 \%[19,60]$. A single-center study demonstrating the effectiveness of 12 months of letrozole found that in addition to the high ORR of $88 \%, 13 \%$ of patients achieved a pCR and less than $10 \%$ of patients progressed [29]. A second single-center study provided further evidence for increased duration of letrozole treatment, with a pCR rate of $2.5 \%$ at 4 months, $5 \%$ at 8 months, and $17.5 \%$ at 12 months [27]. This indicates that the short duration of conventional NET may be the reason behind the low pCR rate frequently observed [27]. A longitudinal phase IV study demonstrated that the median treatment time to allow BCS in previously ineligible patients was 7.5 months, suggesting the conventional duration of 4 months is not optimal [30]. The proportion of patients who became candidates for BCS increased with time, with $66 \%$ of patients suitable after 12 months of letrozole treatment [30]. This was an approximately twofold increase in eligibility for BCS when treatment was 
Table 3 Duration of neoadjuvant endocrine therapy

\begin{tabular}{|c|c|c|c|c|c|}
\hline Study & Duration (months) & Dose (mg/day) & $\begin{array}{l}\text { No. of } \\
\text { patients }\end{array}$ & Study outcomes & Assessment \\
\hline Rusz et al. 2015 [29] & 12 & Letrozole 2.5 & 42 & $\begin{array}{l}\text { 1. pCR: } 14.3 \% \text { operated } \\
\text { cases; } 13 \% \text { overall } \\
\text { 2. ORR (clinical palpation): } 88 \% \\
\text { 3. BCS: } 45 \%\end{array}$ & $\begin{array}{l}\text { Clinical palpation every } \\
3 \text { months. Imaging as } \\
\text { necessary. }\end{array}$ \\
\hline Carpenter et al. 2014 [30] & Up to 12 & Letrozole 2.5 & 139 & $\begin{array}{l}\text { 1. pCR: not reported. } \\
\text { 2. ORR (clinical palpation): } 85 \% \\
\text { (3.2\% CR and } 81.5 \% \text { PR) } \\
\text { 3. BCS: } 66 \% \text { at } 12 \text { months } \\
\text { (all ineligible at baseline) }\end{array}$ & $\begin{array}{l}\text { Clinical examination and } \\
\text { bimodal ultrasound every } \\
2 \text { months until BCS. }\end{array}$ \\
\hline Allevi et al. 2013 [27] & $\begin{array}{l}\text { Randomized to } \\
4,8 \text {, or } 12\end{array}$ & Letrozole 2.5 & 120 & $\begin{array}{l}\text { 1. pCR: } 2.5 \% 4 \text { months; } 5 \% \\
8 \text { months and } 17.5 \% 12 \text { months. } \\
\text { 2. ORR (clinical palpation): } 45 \% \\
\text { 4 months; } 86.8 \% 8 \text { months; } 95 \% \\
12 \text { months. } \\
\text { 3. BCS: } 80 \% 4 \text { months; } 85 \% \\
8 \text { months; } 87.5 \% 12 \text { months. }\end{array}$ & $\begin{array}{l}\text { Monthly clinical palpation } \\
\text { (caliper). Mammography } \\
\text { and ultrasound at baseline } \\
\text { and before surgery. }\end{array}$ \\
\hline $\begin{array}{l}\text { Llombart-Cussac et al. } \\
2012 \text { [73] }\end{array}$ & 3 to 12 & Letrozole 2.5 & 70 & $\begin{array}{l}\text { 1. pCR: } 0 \% \\
\text { 2. ORR (clinical palpation): } 76.8 \% \\
\text { ( } 25 \% \text { CR and } 51.8 \% \text { PR) } \\
\text { 3. BCS: } 43 \%\end{array}$ & $\begin{array}{l}\text { Monthly clinical examination. } \\
\text { Mammogram and ultrasound } \\
\text { every } 8 \text { weeks for first } 4 \text { months. }\end{array}$ \\
\hline Dixon et al. 2009 [71] & 3 to $>24$ months & Letrozole 2.5 & 182 & $\begin{array}{l}\text { 1. pCR: NR. } \\
\text { 2. ORR (clinical palpation): } 69.8 \% \\
\text { 3 months; } 83.5 \%>3 \text { months. } \\
\text { 3. BCS: } 60 \% 3 \text { months; } \\
\text { 72\% > } 3 \text { months. }\end{array}$ & $\begin{array}{l}\text { Clinical measurement and } \\
\text { ultrasound at } 0,2,6 \text {, and } \\
12 \text { weeks. Mammogram at } \\
0 \text { and } 12 \text { weeks. } 3 \text { monthly } \\
\text { review thereafter. }\end{array}$ \\
\hline $\begin{array}{l}\text { Krainick-Strobel et al. } \\
2008 \text { [72] }\end{array}$ & 4 to 8 & Letrozole 2.5 & 32 & $\begin{array}{l}\text { 1. pCR: NR. } \\
\text { 2. ORR (clinical palpation): } 55 \% \\
\text { 4 months; } 72.4 \% 8 \text { months. } \\
\text { 3. BCS: } 75.9 \% \text { (all ineligible } \\
\text { at baseline) }\end{array}$ & $\begin{array}{l}\text { Monthly clinical examination, } \\
\text { ultrasound and mammogram. }\end{array}$ \\
\hline $\begin{array}{l}\text { TEAM IIA Fontein et al. } \\
2014 \text { [70] }\end{array}$ & 3 to 6 & Exemestane 25 & 102 & $\begin{array}{l}\text { 1. pCR: } 0.98 \% \\
\text { 2. ORR (clinical palpation): } \\
58.7 \% 3 \text { months; } 68.3 \% \\
>3 \text { months }(p=0.031) \text {. } \\
\text { 3. BCS: feasibility improved } \\
61.8 \% \text { to } 70.6 \% \text {. }\end{array}$ & $\begin{array}{l}\text { Monthly clinical palpation. } \\
3 \text { monthly MRI, mammogram } \\
\text { or ultrasound. }\end{array}$ \\
\hline $\begin{array}{l}\text { PTEX46 Hojo et al. } \\
2013 \text { [76] }\end{array}$ & 4 or 6 & Exemestane 25 & 52 & $\begin{array}{l}\text { 1. pCR: } 0 \% 4 \text { months; } 4 \% 6 \text { months. } \\
\text { 2. ORR (clinical palpation): } 42.3 \% \\
4 \text { months; } 48 \% 6 \text { months ( } p=0.89 \text { ). } \\
\text { 3. BCS: } 50 \% 4 \text { months; } 48 \% 6 \text { months. }\end{array}$ & $\begin{array}{l}\text { Monthly caliper measurement } \\
\text { and toxicity assessment. } \\
\text { Ultrasound and mammogram } \\
\text { if progression suspected. }\end{array}$ \\
\hline
\end{tabular}

$B C S$ breast-conserving surgery, $p C R$ pathological complete response, $O R R$ objective response rate, $C R$ complete response, $P R$ partial response, $N R$ not reported. See Additional file 1, Table S2 for definitions

extended from 4 to 8 months [30]. An earlier phase II trial from 2012 studied letrozole administration over the period of 4 to 12 months and found that maximal response was achieved in a median time of 4.2 months [73]. However, $37 \%$ of patients continued to improve beyond 6 months and achieved a maximal response within 6 to 12 months, with the ORR increasing from $55 \%$ at 4 months to $76.8 \%$ at the conclusion of the study (Table 3 ) [73]. Other studies which demonstrate the benefit of extending NET are outlined in Table 3 [71, 72]. Interestingly, in the study by Krainick-Strobel et al., of 5 patients who had no change in clinical palpation at 4 months, 1 went on to achieve a complete response and 2 a partial response at 8 months of treatment with letrozole [72]. A retrospective analysis of data in the USA showed that in women who received NET for 1 to 3 months, $20.6 \%$ had their tumors down-staged, compared to down-staging in $34.9 \%$ of those who received NET for 12 to 24 months [69].

Two studies have investigated the optimal duration of NET using exemestane. Exemestane is an irreversible, steroidal aromatase inhibitor which may have fewer adverse effects on the metabolism of lipids and formation of bone when compared to letrozole or anastrozole [77, 78]. The PTEX46 randomized phase II trial found no significant difference in the ORR at 4 or 6 months and suggested the optimal duration of NET is around 4 months (Table 3 ) [76]. In contrast, the TEAM IIA trial found a significant increase in ORR from 3 to 6 months (Table 3) and concluded that in patients without 
progressive disease, extending exemestane treatment from 3 to 6 months improves clinical outcomes without increased toxicity [70].

A concern in recommending extended durations of NET is the challenge in evaluating treatment response, coupled with the possibility of disease progression. Although most studies evaluating primary endocrine treatment have generally compared surgery $+/$ - adjuvant endocrine therapy, with endocrine treatment alone, and therefore represent a different paradigm to NET followed by surgery $+/$ - adjuvant endocrine therapy, it is valuable to note that these studies generally support the safety of NET to at least 12 months if only $\mathrm{ER}^{+}$cases are considered. Reviewed by Macaskill et al. [79] and Pepping et al. [80], it is important to note that most trials of primary endocrine treatment without surgery were not focused on LABC, and earlier trials did not select for ER positivity. Trials that selected on ER positivity found no difference in rates of recurrence and disease-specific outcome $[79,80]$. The 20-year follow-up report of the Nottingham study of 153 fit elderly patients with $\mathrm{ER}^{+}$breast cancer $<5 \mathrm{~cm}$, randomized to primary tamoxifen or mastectomy with adjuvant tamoxifen [81], revealed no difference in regional recurrence, metastasis, disease-specific, or overall survival between groups. Moreover, while locoregional control was poorer longterm in the no surgery cohort, there was no difference between surgery and no surgery groups until at least 18 to 24 months [81]. This is in agreement with Willsher who reported a progression rate of $3 \%$ at 6 months of primary tamoxifen in a cohort selected for high ER, and just 16\% requiring surgery after 3 years [82]. Moreover, partial or complete response at 6 months was a strong predictor of excellent control at 3 years. Mustacchi et al. compared outcomes after primary endocrine therapy with tamoxifen, to surgery followed by adjuvant tamoxifen, in 474 women aged 70 and older [83, 84]. No difference in disease-specific survival was observed between groups after 13 years, and although the progression rate was significantly greater in the tamoxifen only group at 80 months, there was no difference between groups at 12 months [83]. These studies suggest that NET for up to 12 months is safe with close monitoring of tumor burden. Treatment beyond 12 months should be considered with caution.

Recommendation: NET should be continued for at least 6 months. In responders at 6 months, NET should be continued until a maximal clinical response is achieved. The best method to determine "maximal response" in clinical practice is complex and not yet standardized.

\section{Future directions}

Recent studies looking at combining aromatase inhibitors with novel therapies to overcome endocrine resistance have been promising. Phosphatidylinositol 3-kinase (PI3K) inhibitors, including alpelisib and taselisib, have been combined with aromatase inhibitors in a number of recent trials due to the involvement of PI3K-AKT-mTOR pathway upregulation in endocrine resistance $[85,86]$. The large randomized phase II LORELEI trial recruited 334 patients with early-stage $\mathrm{ER}^{+}$breast cancer to letrozole plus taselisib or letrozole plus placebo and demonstrated a significant improvement in ORR in the letrozole plus taselisib group [86].

Of recent interest has been the testing of CDK4/6 inhibitors, as these agents have been shown to enhance the activity of aromatase inhibitors and fulvestrant in advanced disease. The randomized phase II PALLET trial investigated the addition of palbociclib, a CDK4/6 inhibitor, to neoadjuvant letrozole in postmenopausal women with $\mathrm{ER}^{+}$breast cancer [87]. This study found that the addition of a CDK4/6 inhibitor led to a significant reduction in proliferation measured by Ki67, compared to letrozole alone, but no significant improvement in clinical response rates over the 14 week study period [87]. The NeoPAL trial demonstrated that this combination of palbociclib and letrozole produced an almost identical rate of clinical response and rate of BCS compared to patients receiving chemotherapy [88]. In the neoMONARCH study which combined abemaciclib with anastrozole, results have shown significantly reduced levels of Ki67 with the CDK4/6 inhibitor with or without anastrozole, compared to anastrozole alone over 14 weeks of therapy [89]. This study also observed an increase in gene expression associated with immune activation at 2 weeks, but only a modest increase in radiological response rates [89]. The CORALLEEN trial was a randomized phase II trial of 106 patients investigating ribociclib plus letrozole vs. chemotherapy in post-menopausal women with hormone receptor-positive breast cancer of the luminal $\mathrm{B}$ subtype [90]. At the end of the 6 months of the CORALLEEN trial the rate of patients achieving a PEPI of 0 was $17.3 \%$ with chemotherapy and $22.4 \%$ with ribociclib and letrozole [90]. Especially when combining with CDK4/6 inhibitors, NET can achieve high rates of clinical response, even in luminal B patients, as compared with chemotherapy $[87,88,90]$. This is in stark contrast to previous thoughts that NET should be for luminal A patients only. Therefore, the benefit of combination therapies is twofold; firstly, they can increase response in luminal A patients, and secondly, they have expanded the patient population to be considered for NET, sparing the toxicities of chemotherapy.

CDK4/6 inhibitors are approved, in Australia, Europe, and the USA, for treatment of $\mathrm{ER}^{+}$metastatic disease in combination with endocrine therapies. While available 
for LABC, they are not broadly accessible. Currently, ribociclib and palbociclib are available for use in Australia for patients with LABC; however, they are restricted to patients with disease that is deemed inoperable from the outset. These agents are not options for other locally advanced breast cancers where the aim of NET might be to facilitate more restricted breast-conserving surgery or targeted axillary dissection. Investigational treatment strategies combining other targeted agents (including PI3K inhibitors, mTOR inhibitors, and EGFR inhibitors) with endocrine therapies are currently continuing in various clinical trials. In future trial designs, it would be of interest to study not only other novel drug combinations but also to test these combinations over varying treatment durations. Finally, the observation that adding CDK4/6 inhibitors to NET might stimulate anti-tumor immunity [89, 91], as has been observed with some chemotherapy agents [92, 93], suggests that patients with $\mathrm{ER}^{+} \mathrm{LABC}$ could see improved benefit from second-line immunotherapy approaches, while avoiding cytotoxic chemotherapies. Future clinical trials combining NET and novel targeted agents would benefit from including this outcome measure.

\section{Conclusion}

This review has shown that in well-selected patients with $\mathrm{ER}^{+}$breast cancer, NET can lead to significant clinical benefit, both oncological and cosmetic. Good evidence exists for recommending first-line aromatase inhibitors for at least 6 months and should be developed into a clinical guideline. Despite the significant number of trials investigating NET, there is continued underutilization of this therapy and limited discussion of NET at the yearly St. Gallen conference compared to other treatment modalities [39]. The 2019 ESMO Clinical Practice Guidelines agreed that aromatase inhibitors are preferable to tamoxifen and recommended a treatment duration of 4-8 months in the neoadjuvant setting [3]. However, they did not give clear recommendations for patient selection for NET, highlighting the importance of robust guideline development in this area [3]. This review has also highlighted the lack of biomarkers for NET, thereby limiting the confidence in selecting appropriate patients and in measuring outcomes. Moving forward, it is imperative to keep a prospective registry of all NET patients and incorporate tissue collection for future biomarker studies. Finally, this review has demonstrated that the escalation of endocrine maneuvers to de-escalate chemotherapy achieves similar oncological outcomes with a better quality of life for patients.

\section{Supplementary information}

Supplementary information accompanies this paper at https://doi.org/10. 1186/s13058-020-01314-6.

Additional file 1: Table S1. OVID Medline Search Strategy. Table S2. Glossary of Terms and Definitions. Table S3. Allred Score. Table S4:

Preoperative Endocrine Prognostic Index (PEPI) Calculation.

\section{Abbreviations}

ER: Estrogen receptor; PgR: Progesterone receptor; LABC: Locally advanced breast cancer; BCS: Breast-conserving surgery; NET: Neoadjuvant endocrine therapy; NCT: Neoadjuvant chemotherapy; pCR: Pathological complete response; ORR: Objective response rate; RFS: Relapse-free survival

\section{Acknowledgements}

Not applicable

\section{Authors' contributions}

LIM conducted literature searches, evaluated all relevant literature, and wrote the first draft of the manuscript. JDG and PD conceived the topic area, supervised the search strategy and writing, and reviewed and revised the manuscript drafts. All authors read and approved the final manuscript.

\section{Authors' information}

PD is a senior clinical oncologist, with specialization in management of locally advanced and metastatic breast cancer. JDG is a PhD scientist with research focused on endocrine action and endocrine resistance in breast cancer.

\section{Funding}

PD and JDG are supported by the Westmead Breast Cancer Institute, Western Sydney Local Health District.

Availability of data and materials Not applicable

Ethics approval and consent to participate Not applicable

Consent for publication

Not applicable

\section{Competing interests}

The authors declare that they have no competing interests.

\section{Author details}

${ }^{1}$ Sydney Medical School - Westmead, The University of Sydney, Sydney, Australia. ${ }^{2}$ Present Address: South Eastern Sydney Local Health District, and St. George and Sutherland Clinical Schools, UNSW Medicine, Sydney, Australia. ${ }^{3}$ Westmead Breast Cancer Institute, Westmead Hospital, Westmead, Australia. ${ }^{4}$ The Westmead Institute for Medical Research, The University of Sydney, Westmead, Australia.

Received: 7 April 2020 Accepted: 6 July 2020

Published online: 20 July 2020

References

1. Australian Institute of Health and Welfare 2019. Cancer in Australia 2019. Cancer series no.119. Cat. no. CAN 123. Canberra: AlHW; 2019.

2. World Health Organization. Breast Cancer. (2018) https://www.who.int/ cancer/prevention/diagnosis-screening/breast-cancer/en/ Accessed 27 Dec 2019.

3. Cardoso F, Kyriakides S, Ohno S, Penault-Llorca F, Poortmans P, Rubio IT, Zackrisson S, Senkus E. Early breast cancer: ESMO clinical practice guidelines for diagnosis, treatment and follow-up. Ann Oncol. 2019;30(10):1674.

4. Li JJ, Shao ZM. Endocrine therapy as adjuvant or neoadjuvant therapy for breast cancer: selecting the best agents, the timing and duration of treatment. Chin Clin Oncol. 2016;5(3):40. 
5. Jia Y, Song Y, Dong G, Hao C, Zhao W, Li S, Tong Z. Aberrant regulation of RAD51 promotes resistance of neoadjuvant endocrine therapy in ERpositive breast cancer. Sci Rep. 2019;9(1):12939.

6. Kurozumi S, Yamaguchi Y, Matsumoto H, Kurosumi M, Hayashi SI, Fujii T, Horiguchi J, Shirabe K, Inoue K. Utility of Ki67 labeling index, cyclin D1 expression, and ER-activity level in postmenopausal ER-positive and HER2negative breast cancer with neoadjuvant chemo-endocrine therapy. PLoS One. 2019;14(5):e0217279.

7. Valero W, Buzdar AU, Hortobagyi GN. Locally advanced breast Cancer. Oncologist. 1996;1(1 \& 2):8-17.

8. Giordano SH. Update on locally advanced breast cancer. Oncologist. 2003; 8(6):521-30.

9. Vondeling GT, Menezes GL, Dvortsin EP, Jansman FGA, Konings IR, Postma MJ, Rozenbaum MH. Burden of early, advanced and metastatic breast cancer in the Netherlands. BMC Cancer. 2018;18(1):262.

10. Yalcin B. Overview on locally advanced breast cancer: defining, epidemiology, and overview on neoadjuvant therapy. Exp Oncol. 2013;35(4):250-2.

11. Newman LA. Epidemiology of locally advanced breast cancer. Semin Radiat Oncol. 2009;19(4):195-203.

12. Tryfonidis K, Senkus E, Cardoso MJ, Cardoso F. Management of locally advanced breast cancer-perspectives and future directions. Nat Rev Clin Oncol. 2015;12(3):147-62.

13. Harper S, Lynch J, Meersman SC, Breen N, Davis WW, Reichman MC. Trends in area-socioeconomic and race-ethnic disparities in breast cancer incidence, stage at diagnosis, screening, mortality, and survival among women ages 50 years and over (1987-2005). Cancer Epidemiol Biomark Prev. 2009;18(1):121-31.

14. Elting LS, Cooksley CD, Bekele BN, Giordano SH, Shih YC, Lovell KK, Avritscher $E B$, Theriault R. Mammography capacity impact on screening rates and breast cancer stage at diagnosis. Am J Prev Med. 2009;37(2):102-8.

15. El Saghir NS, Adebamowo CA, Anderson BO, Carlson RW, Bird PA, Corbex M, Badwe RA, Bushnaq MA, Eniu A, Gralow JR, Harness JK, Masetti R, Perry F, Samiei M, Thomas DB, Wiafe-Addai B, Cazap E. Breast cancer management in low resource countries ( $L R C s)$ : consensus statement from the breast health global initiative. Breast. 2011;20(Suppl 2):S3-11.

16. Ellis MJ, Ma C. Letrozole in the neoadjuvant setting: the P024 trial. Breast Cancer Res Treat. 2007;105(Suppl 1):33-43.

17. Mamounas EP. Facilitating breast-conserving surgery and preventing recurrence: aromatase inhibitors in the neoadjuvant and adjuvant settings. Ann Surg Oncol. 2008;15(3):691-703.

18. Abrial C, Mouret-Reynier MA, Cure H, Feillel V, Leheurteur M, Lemery S, Le Bouedec G, Durando X, Dauplat J, Chollet P. Neoadjuvant endocrine therapy in breast cancer. Breast. 2006;15(1):9-19.

19. Smith IE, Dowsett M, Ebbs SR, Dixon JM, Skene A, Blohmer JU, Ashley SE, Francis S, Boeddinghaus I, Walsh G. Neoadjuvant treatment of postmenopausal breast cancer with anastrozole, tamoxifen, or both in combination: the Immediate Preoperative Anastrozole, Tamoxifen, or Combined with Tamoxifen (IMPACT) multicenter double-blind randomized trial. J Clin Oncol. 2005;23(22):5108-16.

20. Dowsett M, Smith IE, Ebbs SR, Dixon JM, Skene A, Griffith C, Boeddinghaus I, Salter J, Detre S, Hills M, Ashley S, Francis S, Walsh G, A'Hern R. Proliferation and apoptosis as markers of benefit in neoadjuvant endocrine therapy of breast cancer. Clin Cancer Res. 2006;12(3 Pt 2):1024s-30s.

21. Yeo B, Dowsett M. Neoadjuvant endocrine therapy: patient selection, treatment duration and surrogate endpoints. Breast. 2015;24(Suppl 2):S78-83.

22. Mauriac L, Durand M, Avril A, Dilhuydy JM. Effects of primary chemotherapy in conservative treatment of breast cancer patients with operable tumors larger than $3 \mathrm{~cm}$. Results of a randomized trial in a single centre. Ann Oncol. 1991;2(5):347-54

23. Fisher B, Bryant J, Wolmark N, Mamounas E, Brown A, Fisher ER, Wickerham DL, Begovic M, DeCillis A, Robidoux A, Margolese RG, Cruz AB Jr, Hoehn JL, Lees AW, Dimitrov NV, Bear HD. Effect of preoperative chemotherapy on the outcome of women with operable breast cancer. J Clin Oncol. 1998; 16(8):2672-85.

24. Mauriac L, MacGrogan G, Avril A, Durand M, Floquet A, Debled M, Dilhuydy JM, Bonichon F. Neoadjuvant chemotherapy for operable breast carcinoma larger than $3 \mathrm{~cm}$ : a unicentre randomized trial with a 124-month median follow-up. Institut Bergonie Bordeaux Groupe Sein (IBBGS). Ann Oncol. 1999. 10(1):47-52.

25. Wolmark N, Wang J, Mamounas E, Bryant J, Fisher B. Preoperative chemotherapy in patients with operable breast cancer: nine-year results from National Surgical Adjuvant Breast and Bowel Project B-18. J Natl Cancer Inst Monogr. 2001;30:96-102.

26. Suman VJ, Ellis MJ, Ma CX. The ALTERNATE trial: assessing a biomarker driven strategy for the treatment of post-menopausal women with ER+/ Her2- invasive breast cancer. Chin Clin Oncol. 2015;4(3):34.

27. Allevi G, Strina C, Andreis D, Zanoni V, Bazzola L, Bonardi S, Foroni C, Milani M, Cappelletti MR, Gussago F, Aguggini S, Giardini R, Martinotti M, Fox SB, Harris AL, Bottini A, Berruti A, Generali D. Increased pathological complete response rate after a long-term neoadjuvant letrozole treatment in postmenopausal oestrogen and/or progesterone receptor-positive breast cancer. Br J Cancer. 2013;108(8):1587-92.

28. Lerebours F, Rivera S, Mouret-Reynier MA, Alran S, Venat-Bouvet L, Kerbrat $P$, Salmon R, Becette V, Bourgier C, Cherel P, Boussion V, Balleyguier C, Thibault F, Lavau-Denes S, Nabholz JM, Sigal B, Trassard M, Mathieu MC, Martin AL, Lemonnier J, Mouret-Fourme E. Randomized phase 2 neoadjuvant trial evaluating anastrozole and fulvestrant efficacy for postmenopausal, estrogen receptor-positive, human epidermal growth factor receptor 2negative breast cancer patients: Results of the UNICANCER CARMINA 02 French trial (UCBG 0609). Cancer. 2016;122(19):3032-40.

29. Rusz O, Voros A, Varga Z, Kelemen G, Uhercsak G, Nikolenyi A, Ormandi K, Simonka Z, Kahan Z. One-year neoadjuvant endocrine therapy in breast cancer. Pathol Oncol Res. 2015;21(4):977-84.

30. Carpenter R, Doughty JC, Cordiner C, Moss N, Gandhi A, Wilson C, Andrews C, Ellis G, Gui G, Skene Al. Optimum duration of neoadjuvant letrozole to permit breast conserving surgery. Breast Cancer Res Treat. 2014;144(3):569-76.

31. Methley AM, Campbell S, Chew-Graham C, McNally R, Cheraghi-Sohi S. PICO, PICOS and SPIDER: a comparison study of specificity and sensitivity in three search tools for qualitative systematic reviews. BMC Health Serv Res. 2014;14:579

32. Eriksen MB, Frandsen TF. The impact of patient, intervention, comparison, outcome (PICO) as a search strategy tool on literature search quality: a systematic review. J Med Libr Assoc. 2018;106(4):420-31.

33. Semiglazov VF, Semiglazov W, Dashyan GA, Ziltsova EK, Ivanov VG, Bozhok AA, Melnikova OA, Paltuev RM, Kletzel A, Berstein LM. Phase 2 randomized trial of primary endocrine therapy versus chemotherapy in postmenopausal patients with estrogen receptor-positive breast cancer. Cancer. 2007;110(2):244-54.

34. Palmieri C, Cleator S, Kilburn LS, Kim SB, Ahn SH, Beresford M, Gong G, Mansi J, Mallon E, Reed S, Mousa K, Fallowfield L, Cheang M, Morden J, Page K, Guttery DS, Rghebi B, Primrose L, Shaw JA, Thompson AM, Bliss JM, Coombes RC. NEOCENT: a randomised feasibility and translational study comparing neoadjuvant endocrine therapy with chemotherapy in ER-rich postmenopausal primary breast cancer. Breast Cancer Res Treat. 2014;148(3):581-90.

35. von Minckwitz G, Raab G, Caputo A, Schutte M, Hilfrich J, Blohmer JU, Gerber B, Costa SD, Merkle E, Eidtmann H, Lampe D, Jackisch C, du Bois A, Kaufmann M. Doxorubicin with cyclophosphamide followed by docetaxel every 21 days compared with doxorubicin and docetaxel every 14 days as preoperative treatment in operable breast cancer: the GEPARDUO study of the German Breast Group. J Clin Oncol. 2005;23(12):2676-85.

36. Ellis MJ, Coop A, Singh B, Mauriac L, Llombert-Cussac A, Janicke F, Miller WR, Evans DB, Dugan M, Brady C, Quebe-Fehling E, Borgs M. Letrozole is more effective neoadjuvant endocrine therapy than tamoxifen for ErbB-1- and/or ErbB-2-positive, estrogen receptor-positive primary breast cancer: evidence from a phase III randomized trial. J Clin Oncol. 2001;19(18):3808-16.

37. Qureshi A, Pervez S. Allred scoring for ER reporting and it's impact in clearly distinguishing ER negative from ER positive breast cancers. J Pak Med Assoc. 2010;60(5):350-3.

38. Barnadas A, Gil M, Gonzalez S, Tusquets I, Munoz M, Arcusa A, Prieto L, Margeli-Vila M, Moreno A. Exemestane as primary treatment of oestrogen receptor-positive breast cancer in postmenopausal women: a phase II trial. Br J Cancer. 2009;100(3):442-9.

39. Burstein HJ, Curigliano G, Loibl S, Dubsky P, Gnant M, Poortmans P, Colleoni M, Denkert C, Piccart-Gebhart M, Regan M, Senn HJ, Winer EP, Thurlimann B. Estimating the benefits of therapy for early-stage breast cancer: the St. Gallen International Consensus Guidelines for the primary therapy of early breast cancer 2019. Ann Oncol. 2019;30(10):1541-57.

40. Miller WR, Larionov A, Anderson TJ, Walker JR, Krause A, Evans DB, Dixon $J M$. Predicting response and resistance to endocrine therapy: profiling patients on aromatase inhibitors. Cancer. 2008;112(3 Suppl):689-94. 
41. Ellis MJ, Tao Y, Luo J, A'Hern R, Evans DB, Bhatnagar AS, Chaudri Ross HA, von Kameke A, Miller WR, Smith I, Eiermann W, Dowsett M. Outcome prediction for estrogen receptor-positive breast cancer based on postneoadjuvant endocrine therapy tumor characteristics. J Natl Cancer Inst. 2008;100(19):1380-8.

42. Giridhar KV, Liu MC. Available and emerging molecular markers in the clinical management of breast cancer. Expert Rev Mol Diagn. 2019;19(10): 919-28.

43. Goto-Yamaguchi L, Yamamoto-Ibusuki M, Yamamoto Y, Fujiki Y, Tomiguchi M, Sueta A, Takeshita T, Iwase $H$. Therapeutic predictors of neoadjuvant endocrine therapy response in estrogen receptor-positive breast cancer with reference to optimal gene expression profiling. Breast Cancer Res Treat. 2018;172(2):353-62.

44. Gyorffy B, Hatzis C, Sanft T, Hofstatter E, Aktas B, Pusztai L. Multigene prognostic tests in breast cancer: past, present, future. Breast Cancer Res. 2015;17:11.

45. Russnes HG, Lingjaerde OC, Borresen-Dale AL, Caldas C. Breast cancer molecular stratification: from intrinsic subtypes to integrative clusters. Am J Pathol. 2017;187(10):2152-62

46. Selli C, Turnbull AK, Pearce DA, Li A, Fernando A, Wills J, Renshaw L, Thomas JS, Dixon JM, Sims AH. Molecular changes during extended neoadjuvant letrozole treatment of breast cancer: distinguishing acquired resistance from dormant tumours. Breast Cancer Res. 2019;21(1):2.

47. Inda MA, Blok EJ, Kuppen PJK, Charehbili A, den Biezen-Timmermans EC, van Brussel A, Fruytier SE, Meershoek-Klein Kranenbarg E, Kloet SL, van der Burg B, Martens JWM, Sims AH, Turnbull AK, Dixon JM, Verhaegh W, Kroep $J R$, van de Velde $\mathrm{CJH}$, van de Stolpe A: Estrogen Receptor pathway activity score to predict clinical response or resistance to neo-adjuvant endocrine therapy in primary breast cancer. Mol Cancer Ther. 2019;19(2):680-89.

48. Ueno T, Saji S, Masuda N, Iwata H, Kuroi K, Sato N, Takei H, Yamamoto $Y$, Ohno S, Yamashita H, Hisamatsu K, Aogi K, Sasano H, Toi M. Changes in recurrence score by neoadjuvant endocrine therapy of breast cancer and their prognostic implication. ESMO Open. 2019;4(1):e000476.

49. Bear HD, Wan W, Robidoux A, Rubin P, Limentani S, White RL Jr, Granfortuna J, Hopkins JO, Oldham D, Rodriguez A, Sing AP. Using the 21gene assay from core needle biopsies to choose neoadjuvant therapy for breast cancer: a multicenter trial. J Surg Oncol. 2017;115(8):917-23.

50. Akashi-Tanaka S, Shimizu C, Ando M, Shibata T, Katsumata N, Kouno T, Terada K, Shien T, Yoshida M, Hojo T, Kinoshita T, Fujiwara Y, Yoshimura K. 21-gene expression profile assay on core needle biopsies predicts responses to neoadjuvant endocrine therapy in breast cancer patients. Breast. 2009; 18(3):171-4.

51. Paik S, Shak S, Tang G, Kim C, Baker J, Cronin M, Baehner FL, Walker MG, Watson D, Park T, Hiller W, Fisher ER, Wickerham DL, Bryant J, Wolmark N. A multigene assay to predict recurrence of tamoxifen-treated, node-negative breast cancer. N Engl J Med. 2004;351(27):2817-26.

52. Iwata H, Masuda N, Yamamoto Y, Fujisawa T, Toyama T, Kashiwaba M Ohtani S, Taira N, Sakai T, Hasegawa Y, Nakamura R, Akabane H, Shibahara Y, Sasano H, Yamaguchi T, Sakamaki K, Bailey H, Cherbavaz DB, Jakubowski DM, Sugiyama N, Chao C, Ohashi Y. Validation of the 21-gene test as a predictor of clinical response to neoadjuvant hormonal therapy for ER+, HER2-negative breast cancer: the TransNEOS study. Breast Cancer Res Treat. 2019;173(1):123-33.

53. Ellis MJ, Suman VJ, Hoog J, Goncalves R, Sanati S, Creighton CJ, DeSchryver K, Crouch E, Brink A, Watson M, Luo J, Tao Y, Barnes M, Dowsett M, Budd GT, Winer E, Silverman P, Esserman L, Carey L, Ma CX, Unzeitig G, Pluard T, Whitworth P, Babiera G, Guenther JM, Dayao Z, Ota D, Leitch M, Olson JA Jr, Allred DC, Hunt K. Ki67 proliferation index as a tool for chemotherapy decisions during and after neoadjuvant aromatase inhibitor treatment of breast cancer: results from the American College of Surgeons Oncology Group Z1031 Trial (Alliance). J Clin Oncol. 2017;35(10):1061-9.

54. Ellis MJ, Suman VJ, Hoog J, Lin L, Snider J, Prat A, Parker JS, Luo J, Deschryver K, Allred DC, Esserman LJ, Unzeitig GW, Margenthaler J, Babiera GV, Marcom PK, Guenther JM, Watson MA, Leitch M, Hunt K, Olson JA Randomized phase II neoadjuvant comparison between letrozole, anastrozole, and exemestane for postmenopausal women with estrogen receptor-rich stage 2 to 3 breast cancer: clinical and biomarker outcomes and predictive value of the baseline PAM50-based intrinsic subtype-ACOSOG Z1031. J Clin Oncol. 2011;29(17):2342-9.

55. Gao JJ, Swain SM. Luminal a breast cancer and molecular assays: a review. Oncologist. 2018;23(5):556-65.
56. Prat A, Cheang MC, Martin M, Parker JS, Carrasco E, Caballero R, Tyldesley S, Gelmon K, Bernard PS, TO N, Perou CM. Prognostic significance of progesterone receptor-positive tumor cells within immunohistochemically defined luminal A breast cancer. J Clin Oncol. 2013;31(2):203-9.

57. Kurozumi S, Matsumoto H, Inoue K, Tozuka K, Hayashi Y, Kurosumi M, Oyama T, Fujii T, Horiguchi J, Kuwano H. Impact of combining the progesterone receptor and preoperative endocrine prognostic index (PEPI) as a prognostic factor after neoadjuvant endocrine therapy using aromatase inhibitors in postmenopausal ER positive and HER2 negative breast cancer. PLoS One. 2018;13(8):e0201846.

58. Vendrell JA, Solassol J, Gyorffy B, Vilquin P, Jarlier M, Donini CF, Gamba L, Maudelonde T, Rouanet P, Cohen PA. Evaluating ZNF217 mRNA expression levels as a predictor of response to endocrine therapy in ER+ breast cancer. Front Pharmacol. 2018;9:1581.

59. Eiermann W, Paepke S, Appfelstaedt J, Llombart-Cussac A, Eremin J, Vinholes J, Mauriac L, Ellis M, Lassus M, Chaudri-Ross HA, Dugan M, Borgs M. Preoperative treatment of postmenopausal breast cancer patients with letrozole: a randomized double-blind multicenter study. Ann Oncol. 2001; 12(11):1527-32.

60. Cataliotti L, Buzdar AU, Noguchi S, Bines J, Takatsuka Y, Petrakova K, Dube P, de Oliveira CT. Comparison of anastrozole versus tamoxifen as preoperative therapy in postmenopausal women with hormone receptor-positive breast cancer: the Pre-Operative "Arimidex" Compared to Tamoxifen (PROACT) trial. Cancer. 2006;106(10):2095-103.

61. Ellis MJ, Coop A, Singh B, Tao Y, Llombart-Cussac A, Janicke F, Mauriac L, Quebe-Fehling E, Chaudri-Ross HA, Evans DB, Miller WR. Letrozole inhibits tumor proliferation more effectively than tamoxifen independent of HER1/2 expression status. Cancer Res. 2003;63(19):6523-31.

62. Paridaens R, Dirix L, Lohrisch C, Beex L, Nooij M, Cameron D, Biganzoli L, Cufer T, Duchateau L, Hamilton A, Lobelle JP, Piccart M. Mature results of a randomized phase II multicenter study of exemestane versus tamoxifen as first-line hormone therapy for postmenopausal women with metastatic breast cancer. Ann Oncol. 2003;14(9):1391-8.

63. Akashi-Tanaka S, Omatsu M, Shimizu C, Ando M, Terada K, Shien T, Kinoshita T, Fujiwara Y, Seki K, Hasegawa T, Fukutomi T. Favorable outcome in patients with breast cancer in the presence of pathological response after neoadjuvant endocrine therapy. Breast. 2007;16(5):482-8.

64. Semiglazov V, Kletsel A, Semiglazov V, Zhiltzova E, Ivanov V, Dashyan G, Bozhok A, Melnikova O, Paltuev R, Berstein L. Exemestane (E) vs tamoxifen $(T)$ as neoadjuvant endocrine therapy for postmenopausal women with ER+ breast cancer (T2N1-2, T3N0-1, T4N0M0). J Clin Oncol. 2005;23(16_suppl):530.

65. Grassadonia A, Di Nicola M, Grossi S, Noccioli P, Tavoletta S, Politi R, Angelucci D, Marinelli C, Zilli M, Ausili Cefaro G, Tinari N, De Tursi M, lezzi L, Cioffi P, lacobelli S, Natoli C, Cianchetti E. Long-term outcome of neoadjuvant endocrine therapy with aromatase inhibitors in elderly women with hormone receptor-positive breast cancer. Ann Surg Oncol. 2014;21(5): 1575-82.

66. Robertson JF, Llombart-Cussac A, Rolski J, Feltl D, Dewar J, Macpherson E, Lindemann J, Ellis MJ. Activity of fulvestrant $500 \mathrm{mg}$ versus anastrozole 1 $\mathrm{mg}$ as first-line treatment for advanced breast cancer: results from the FIRST study. J Clin Oncol. 2009;27(27):4530-5.

67. Olson JA Jr, Budd GT, Carey LA, Harris LA, Esserman LJ, Fleming GF, Marcom PK, Leight GS Jr, Giuntoli T, Commean P, Bae K, Luo J, Ellis MJ. Improved surgical outcomes for breast cancer patients receiving neoadjuvant aromatase inhibitor therapy: results from a multicenter phase II trial. J Am Coll Surg. 2009;208(5):906-14.

68. Morigi C. Highlights from the 15th St Gallen International Breast Cancer Conference 15-18 March, 2017, Vienna: tailored treatments for patients with early breast cancer. Ecancermedicalscience. 2017;11:732.

69. Pariser AC, Sedghi T, Soulos PR, Killelea B, Gross CP, Mougalian SS. Utilization, duration, and outcomes of neoadjuvant endocrine therapy in the United States. Breast Cancer Res Treat. 2019;178(2):419-26.

70. Fontein DB, Charehbili A, Nortier JW, Meershoek-Klein Kranenbarg E, Kroep $J R$, Putter H, van Riet Y, Nieuwenhuijzen GA, de Valk B, Terwogt JM, Algie GD, Liefers GJ, Linn S, van de Velde CJ. Efficacy of six month neoadjuvant endocrine therapy in postmenopausal, hormone receptor-positive breast cancer patients--a phase II trial. Eur J Cancer. 2014;50(13):2190-200.

71. Dixon JM, Renshaw L, Macaskill EJ, Young O, Murray J, Cameron D, Kerr GR, Evans DB, Miller WR. Increase in response rate by prolonged treatment with neoadjuvant letrozole. Breast Cancer Res Treat. 2009;113(1):145-51. 
72. Krainick-Strobel UE, Lichtenegger W, Wallwiener D, Tulusan AH, Janicke F, Bastert G, Kiesel L, Wackwitz B, Paepke S. Neoadjuvant letrozole in postmenopausal estrogen and/or progesterone receptor positive breast cancer: a phase IIb/III trial to investigate optimal duration of preoperative endocrine therapy. BMC Cancer. 2008:8:62.

73. Llombart-Cussac A, Guerrero A, Galan A, Caranana V, Buch E, RodriguezLescure A, Ruiz A, Fuster Diana C, Guillem Porta V. Phase II trial with letrozole to maximum response as primary systemic therapy in postmenopausal patients with ER/PgR[+] operable breast cancer. Clin Transl Oncol. 2012;14(2):125-31.

74. Goldhirsch A, Winer EP, Coates AS, Gelber RD, Piccart-Gebhart M, Thurlimann B, Senn HJ. Personalizing the treatment of women with early breast cancer: highlights of the St Gallen International Expert Consensus on the Primary Therapy of Early Breast Cancer 2013. Ann Oncol. 2013;24(9): 2206-23.

75. Harbeck N, Thomssen C, Gnant M. St. Gallen 2013: brief preliminary summary of the consensus discussion. Breast Care (Basel). 2013:8(2):102-9.

76. Hojo T, Kinoshita T, Imoto S, Shimizu C, Isaka H, Ito H, Imi K, Wada N, Ando M, Fujiwara Y. Use of the neo-adjuvant exemestane in post-menopausal estrogen receptor-positive breast cancer: a randomized phase II tria (PTEX46) to investigate the optimal duration of preoperative endocrine therapy. Breast. 2013;22(3):263-7.

77. Mlineritsch B, Tausch C, Singer C, Luschin-Ebengreuth $G$, Jakesz R, Ploner F, Stierer M, Melbinger E, Menzel C, Urbania A, Fridrik M, Steger G, Wohlmuth $P$, Gnant M, Greil R. Exemestane as primary systemic treatment for hormone receptor positive post-menopausal breast cancer patients: a phase II trial of the Austrian Breast and Colorectal Cancer Study Group (ABCSG-17). Breast Cancer Res Treat. 2008;112(1):203-13.

78. Takei H, Suemasu K, Inoue K, Saito T, Okubo K, Koh J, Sato K, Tsuda H, Kurosumi M, Tabei T. Multicenter phase II trial of neoadjuvant exemestane for postmenopausal patients with hormone receptor-positive, operable breast cancer: Saitama Breast Cancer Clinical Study Group (SBCCSG-03). Breast Cancer Res Treat. 2008;107(1):87-94.

79. Macaskill EJ, Dixon JM. Neoadjuvant use of endocrine therapy in breast cancer. Breast J. 2007;13(3):243-50.

80. Pepping RMC, Portielje JEA, van de Water W, de Glas NA. Primary endocrine therapy in older women with breast cancer. Curr Geriatr Rep. 2017;6(4):23946 .

81. Johnston SJ, Kenny FS, Syed BM, Robertson JF, Pinder SE, Winterbottom L, Ellis IO, Blamey RW, Cheung KL. A randomised trial of primary tamoxifen versus mastectomy plus adjuvant tamoxifen in fit elderly women with invasive breast carcinoma of high oestrogen receptor content: long-term results at 20 years of follow-up. Ann Oncol. 2012;23(9):2296-300.

82. Willsher PC, Robertson JFR, Jackson L, Al-Hilaly M, Blamey RW. Investigation of primary tamoxifen therapy for elderly patients with operable breast cancer. Breast. 1997;6:150-4.

83. Mustacchi G, Ceccherini R, Milani S, Pluchinotta A, De Matteis A, Maiorino L, Farris A, Scanni A, Sasso F, Italian Cooperative Group G. Tamoxifen alone versus adjuvant tamoxifen for operable breast cancer of the elderly: longterm results of the phase III randomized controlled multicenter GRETA trial. Ann Oncol. 2003;14(3):414-20.

84. Mustacchi G, Milani S, Pluchinotta A, De Matteis A, Rubagotti A, Perrota A. Tamoxifen or surgery plus tamoxifen as primary treatment for elderly patients with operable breast cancer: The G.R.E.T.A. Trial. Group for research on endocrine therapy in the elderly. Anticancer Res. 1994;14(5B):2197-200.

85. Jackisch C. Overcoming endocrine resistance in neoadjuvant endocrine therapy for early breast cancer. Lancet Oncol. 2019;20(9):1185-7.

86. Saura C, Hlauschek D, Oliveira M, Zardavas D, Jallitsch-Halper A, de la Pena L, Nuciforo P, Ballestrero A, Dubsky P, Lombard JM, Vuylsteke P, Castaneda CA, Colleoni M, Santos Borges G, Ciruelos E, Fornier M, Boer K, Bardia A, Wilson TR, Stout TJ, Hsu JY, Shi Y, Piccart M, Gnant M, Baselga J, de Azambuja E. Neoadjuvant letrozole plus taselisib versus letrozole plus placebo in postmenopausal women with oestrogen receptor-positive, HER2-negative, early-stage breast cancer (LORELEI): a multicentre, randomised, double-blind, placebo-controlled, phase 2 trial. Lancet Oncol. 2019;20(9):1226-38.

87. Johnston S, Puhalla S, Wheatley D, Ring A, Barry P, Holcombe C, Boileau JF, Provencher L, Robidoux A, Rimawi M, SA MI, Shalaby I, Stein RC, Thirlwell M, Dolling D, Morden J, Snowdon C, Perry S, Cornman C, Batten LM, Jeffs LK, Dodson A, Martins V, Modi A, Osborne CK, Pogue-Geile KL, MCU C, Wolmark N, Julian TB, Fisher K, MacKenzie M, Wilcox M, Huang Bartlett C, Koehler M,
Dowsett M, Bliss JM, Jacobs SA. Randomized phase II study evaluating palbociclib in addition to letrozole as neoadjuvant therapy in estrogen receptor-positive early breast cancer: PALLET trial. J Clin Oncol. 2019;37(3): 178-89.

88. Cottu P, D'Hondt V, Dureau S, Lerebours F, Desmoulins I, Heudel PE, Duhoux FP, Levy C, Mouret-Reynier MA, Dalenc F, Frenel JS, Jouannaud C, Venat-Bouvet L, Nguyen S, Ferrero JM, Canon JL, Grenier J, Callens C, Gentien D, Lemonnier J, Vincent-Salomon A, Delaloge S. Letrozole and palbociclib versus chemotherapy as neoadjuvant therapy of high-risk luminal breast cancer. Ann Oncol. 2018;29(12):2334-40.

89. Hurvitz SA, Martin M, Press MF, Chan D, Fernandez-Abad M, Petru E, Rostorfer R, Guarneri V, Huang CS, Barriga S, Wijayawardana S, Brahmachary M, Ebert PJ, Hossain A, Liu J, Abel A, Aggarwal A, Jansen VM, Slamon DJ. Potent cell-cycle inhibition and upregulation of immune response with abemaciclib and anastrozole in neoMONARCH, phase II neoadjuvant study in HR(+)/HER2(-) breast cancer. Clin Cancer Res. 2020;26(3):566-80.

90. Prat A, Saura C, Pascual T, Hernando C, Munoz M, Pare L, Gonzalez Farre B, Fernandez PL, Galvan P, Chic N, Gonzalez Farre X, Oliveira M, Gil-Gil M, Arumi M, Ferrer N, Montano A, Izarzugaza Y, Llombart-Cussac A, Bratos R, Gonzalez Santiago S, Martinez E, Hoyos S, Rojas B, Virizuela JA, Ortega V, Lopez R, Celiz P, Ciruelos E, Villagrasa P, Gavila J. Ribociclib plus letrozole versus chemotherapy for postmenopausal women with hormone receptorpositive, HER2-negative, luminal B breast cancer (CORALLEEN): an openlabel, multicentre, randomised, phase 2 trial. Lancet Oncol. 2020;21(1):33-43.

91. Goel S, DeCristo MJ, Watt AC, BrinJones H, Sceneay J, Li BB, Khan N, Ubellacker JM, Xie S, Metzger-Filho O, Hoog J, Ellis MJ, Ma CX, Ramm S, Krop IE, Winer EP, Roberts TM, Kim HJ, McAllister SS, Zhao JJ. CDK4/6 inhibition triggers anti-tumour immunity. Nature. 2017;548(7668):471-5.

92. Voorwerk L, Slagter M, Horlings HM, Sikorska K, van de Vijver KK, de Maaker M, Nederlof I, RJC K, Warren S, Ong S, Wiersma TG, Russell NS, Lalezari F, Schouten PC, NAM B, SLC K, Peters D, CAH L, van Werkhoven E, van Tinteren H, IAM M, Kemper I, Onderwater S, Chalabi M, Wilgenhof S, Haanen J, Salgado R, de Visser KE, Sonke GS, LFA W, Linn SC, Schumacher TN, Blank $\mathrm{CU}$, Kok M. Immune induction strategies in metastatic triple-negative breast cancer to enhance the sensitivity to PD-1 blockade: the TONIC trial. Nat Med. 2019;25(6):920-8.

93. Schmid P, Cortes J, Pusztai L, McArthur H, Kummel S, Bergh J, Denkert C, Park YH, Hui R, Harbeck N, Takahashi M, Foukakis T, Fasching PA, Cardoso F, Untch M, Jia L, Karantza V, Zhao J, Aktan G, Dent R, O'Shaughnessy J. Investigators K-: pembrolizumab for early triple-negative breast cancer. N Engl J Med. 2020;382(9):810-21.

\section{Publisher's Note}

Springer Nature remains neutral with regard to jurisdictional claims in published maps and institutional affiliations. 